\title{
Colorimetry to assess the visual impact of dust deposition on mosaics at sheltered archaeological sites
}

\author{
Cristina Cabello Briones ${ }^{1 *}$, Santiago Mayorga Pinilla ${ }^{2} \mathbb{D}$, Daniel Vázquez Moliní ${ }^{2}$ and \\ Antonio Álvarez Fernández-Balbuena² (1)
}

\begin{abstract}
One of the most important alteration factors for archaeological sites is the deposition of dust, primarily onto horizontal surfaces, because it affects both the conservation state of the remains and their appearance. The deposition is responsible for visual changes that prevent proper appreciation of the site, and this is especially negative for the decorative elements such as mosaics. Dust deposition has been seen as a significant problem in sheltered sites as opposed to those located in the open air, where deposits are regularly washed away. However, there is a lack of knowledge on the visual effects of dust on sheltered archaeological remains despite the fact that this information could help to determine cleaning regimes. This research has been undertaken at the House of Hippolytus, a Roman villa located on the outskirts of Complutum, situated where the city of Alcalá de Henares (Spain) stands today. The site was covered with a partially enclosed shelter in 1999 and it contains a magnificent mosaic in the central area. This ornamental floor is the center of attention for visitors and has often been used as a promotional image because of its high artistic value. This study has objectively evaluated the visual changes (color and spectral characteristics) of the mosaic at the House of Hippolytus before and after being cleaned with dry and wet systems using a novel approach based not only on a spectrophotometer (CM-2600d Konica Minolta ${ }^{\circledR}$ ) but also on a LumiCam ${ }^{\circledR} 1300$ camera (Instrument Systems GmbH). Although wet cleaning implies the use of water, which is a decay factor, it has been found to be the best option for recovering the original aspect of the mosaic.
\end{abstract}

Keywords: Chroma, Lightness, Hue angle, Reflectance, LumiCam ${ }^{\circledR}$, Spectrophotometer, Complutum

\section{Introduction}

Deposition of particulate matter can lead to physical and chemical modifications of exposed surfaces, resulting in a great variety of decay forms such as those complied by Brimblecombe [1], for example, surface erosion and formation of crusts in the case of stone. Dust deposition is also an important alteration factor for archaeological sites as it is responsible of visual nuisance, especially

\footnotetext{
*Correspondence: cristina.cabello@uam.es

${ }^{1}$ Service for the Conservation, Restoration and Scientific Studies of Archaeological Heritage (SECYR), Facultad de Filosofía y Letras, Universidad Autónoma de Madrid, Módulo X Planta Baja, 28049 Madrid, Spain

Full list of author information is available at the end of the article
}

harmful for colorful decorative elements (mosaics, tiles and mural paintings). Coarse particles have a larger potential for visual alteration as they lead to coverage of a higher proportion of surfaces, however the accumulation of fine particles can also produce nuisance [2]. Deposition is particularly negative for floor mosaics. Horizontal surfaces are extremely affected by coarse particles, which have shorter suspension time and tend to accumulate on the ground [3]. These pavements make use of colorful tesserae arranged to create decorative patterns with depth and movement, and apart from having an important role on the iconographic program, are highly responsible for the artistic significance of a site.
Springer Open

(c) The Author(s) 2021. This article is licensed under a Creative Commons Attribution 4.0 International License, which permits use, sharing adaptation, distribution and reproduction in any medium or format, as long as you give appropriate credit to the original author(s) and the source, provide a link to the Creative Commons licence, and indicate if changes were made. The images or other third party material in this article are included in the article's Creative Commons licence, unless indicated otherwise in a credit line to the material. If material is not included in the article's Creative Commons licence and your intended use is not permitted by statutory regulation or exceeds the permitted use, you will need to obtain permission directly from the copyright holder. To view a copy of this licence, visit http://creativeco mmons.org/licenses/by/4.0/. The Creative Commons Public Domain Dedication waiver (http://creativecommons.org/publicdomain/ zero/1.0/) applies to the data made available in this article, unless otherwise stated in a credit line to the data. 
Dry deposition has been seen as a significant problem in sheltered sites as opposed to those located in the open air, which are exposed to stronger winds and direct rainwater that carry the deposits away [4-6]. However, this is still an understudied topic. Regarding the visual effects, previous research has focused on soiling in the case of outdoor monuments [7]. Soiling can be defined as a general darkening of the surface due to the deposition of atmospheric particles [8] and it has been particularly studied for building materials [9]. The darkening effect relates to carbonaceous particles, which presents high optical absorptivity. These particles come primarily from road traffic emissions, particularly diesel [1], although biological activity can also contribute [10]. The current trend in pollution, which corresponds to lower concentrations of elemental carbon and increasing amounts of nitrate, has led to other forms of discoloration such as the yellowing related to organic rich deposits [11]. This may imply a future change in the visitors' perception to more sensitivity towards hue and chroma instead of lightness [7]. Research has also focused on the consequences of indoor dust for the visitor's experience in museums and historic houses [12-14]. It has been corroborated that cumulative deposits reduce both aesthetic and evidential value, making visitors have a negative impression of the site [12].

The visual impact of dust deposition on heritage materials has usually been evaluated by studying the loss of reflectance with a spectrophotometer. According to Bellan, Salmon and Cass [15], a 10\% loss is associated to a visible change. However, significant adverse reactions from the public are only linked with a minimum of $35 \%$ reduction in reflectance [16]. The perception of soiling can also be represented by the contrast of clean and dirty surfaces [7]. Brimblecombe and Grossi [9] determined that there was a strong relationship between the lightness of a surface and the appreciation of dirtiness. In addition, the distribution of the darkening patterns is important as it can contribute to stronger adverse responses from the public, for instance, if soiling obscures design details or lines [17]. Moreover, small number of large particles can cause the same appearance of soiling as smaller ones in higher concentration. This is especially important for museums where soil dust, fiber, plant fragments and insect parts are frequently found [18].

According to Cobau and Nardi [19], dry cleaning of in situ archaeological mosaics should be undertaken more frequently than wet cleaning. Recurrent wet treatments to remove dirt and decay products can enhance the breakdown of fragile, porous, or weathered surfaces. Water is a key factor involved in freeze-thaw and salt crystallization events, which can lead to inner pressures. In addition, wetting cycles can induce chemical reactions and variations in moisture content that may cause biological growth or expansion and contraction of layers [20].

Visual changes related to the deposition of dust on horizontal archaeological surfaces, which is one of the main consequences of sheltering, have been studied here for the first time. These changes were objectively evaluated by comparing the mosaic at the House of Hippolytus before (with a 6-week dust layer) and after being cleaned. In addition, this research assesses the results of both dry and wet cleaning on the aspect of a mosaic, so better decisions about its regular care can be taken.

\section{Case-study}

The House of Hippolytus was a suburb of the Roman city of Complutum $\left(40^{\circ} 28^{\prime} 26.146^{\prime \prime} \mathrm{N}, 3^{\circ} 23^{\prime} 16.49^{\prime \prime} \mathrm{W}\right)$. This archaeological site, dated from the 1st to fourth century CE, is located where the modern town of Alcala de Henares currently stands (30 km from Madrid, Spain). As part of the historic precinct of Alcala de Henares, the site has been included in the UNESCO World Heritage list since 1999.

The name of the House relates to an epigraphy on the main mosaic (of around the third century $\mathrm{CE}$ ), which presumably corresponds to the master of the villa [21]. This ornamental floor in the central courtyard of the thermal complex is a horizontal surface of opus tessellatum made predominantly of limestone tiles [22]. The tesserae have irregular shapes but their size is approximately of $4.5 \times 4.5 \mathrm{~mm}$. The piece with higher artistic value, at the SE corner of the mosaic, represents a fishing scene with three Cupids sailing on a boat surrounded by Mediterranean fauna, a traditionally North African tradition [23].

The site was sheltered in 1999 with a structure made of bricks in the lower part and galvanized metallic meshes in the upper part of the perimeter walls (Fig. 1). It was covered with sheets of galvanized steel on the outer side and hydrophobic agglomerate boards on the inner side, all of which is supported by metallic beams [24]. Although this type of structure allows some air exchange through the lateral cladding, it can be described as a semi enclosure due to its partially enclosed design in contrast to a completely open shelter. The intention behind the shelter was the musealization of the site, along with providing protection for the remains [25].

A walkway runs along the periphery of the site and allows an aerial view. Apart from the natural light coming from the sides and the skylight in the cover, the remains are illuminated with fluorescent lamps anchored to the shelter structure. As musealization was a priority, the appreciation of the remains is utterly important. In the final report of the restoration intervention carried out in this area in 2018, it was mentioned that the mosaics presented a high degree of 


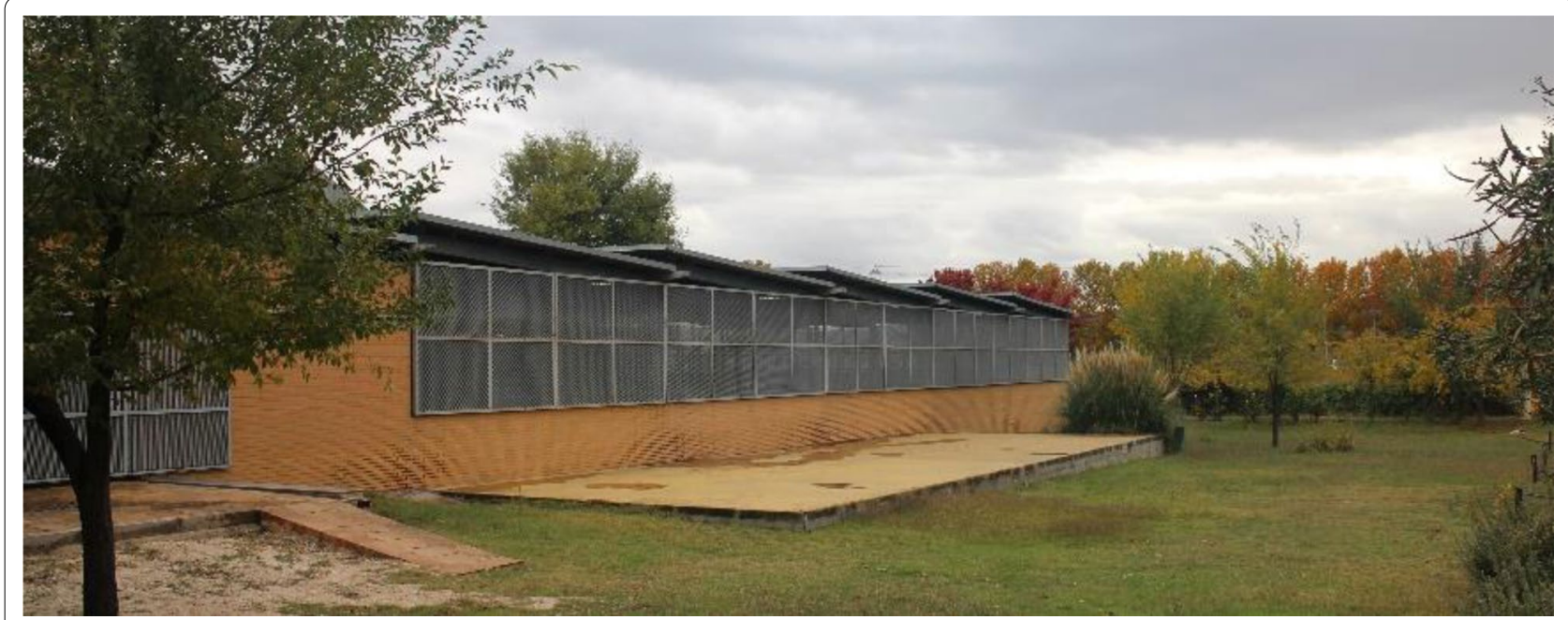

Fig. 1 House of Hippolytus from outside in Complutum (Alcala de Henares, Spain)

superficial dirt, which impeded the correct interpretation of the iconography, in addition to being a possible cause of decay [26].

The maintenance plan includes periodic cleaning of the surfaces. Although the rationale behind the frequency is subjective, the process approximately coincides with a dry cleaning (brushing) once every month and a half, and a wet cleaning (mopping) every 3 months.

\section{Methods and materials}

With the purpose of obtaining objective, quantitative values on the visual consequences of dust deposition on archaeological mosaics, a study was undertaken based on image and spectral measurements of the mosaic at the House of Hippolytus. The surface of the mosaic is considerably large $(7.50 \times 3.80 \mathrm{~m})$ so the study focused on the three Cupids scene (Fig. 2) which has a wide diversity of colors and is a representative area of the complex.

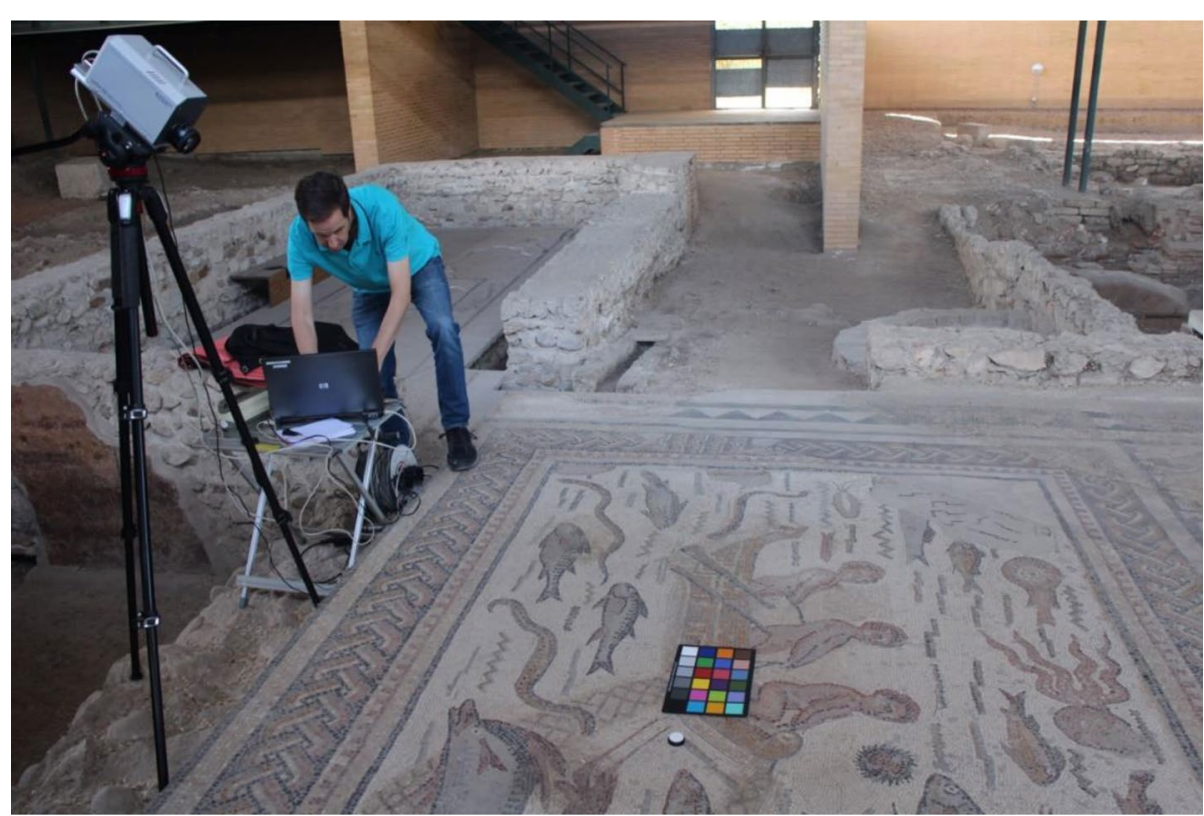

Fig. 2 Detail of the mosaic at the House of Hippolytus, where the measurements were undertaken 
The measurements were taken after 6 weeks of exposure (from 23rd April to 5th June 2019) and before any type of cleaning $\left(\mathrm{m}_{0}\right)$. The same procedure was repeated after a dry cleaning process by sweeping $\left(\mathrm{m}_{1}\right)$, and a wet one by mopping $\left(\mathrm{m}_{2}\right)$. In this case the measurements were undertaken after the surface was dry. Therefore the results of the last stage included both the dry and wet cleaning.

The methodology is based on the use of a spectrophotometer, as in previous research regarding quantification of visual changes on heritage materials, but this research has also made use of a LumiCam ${ }^{\circledR} 1300$ camera, unprecedented for this purpose. This portable set of methods provided unambiguous information about color and reflectance of a complete sector of the mosaic and a particular group of tesserae selected by their color.

\section{Colorimetric changes of the mosaic}

The colorimetric study of the chosen part of the mosaic has permitted knowing the lightless, chroma and hue angle of all tesserae, and determining how these values have changed with the cleaning process, including the color difference after each cleaning stage.

The study was undertaken by means of a LumiCam ${ }^{\circledR}$ 1300 camera (Instrument Systems $\mathrm{GmbH}$ ), which has a resolution of $1360 \times 1010$ pixels (Fig. 2). The method provided the luminance $\left(\mathrm{L}\right.$, in $\left.\mathrm{cd} / \mathrm{m}^{2}\right)$, tri-stimuli $(X, Y, Z)$ and $R G B$ values of each pixel, data later processed by the camera software. As calibration references, a 75\% reflectance white checker (Spectralon ${ }^{\circledR}$ by Labsphere) and an $\mathrm{X}$-Rite Colorchecker ${ }^{\circledR}$ panel were placed on the ground next to the main scene (Fig. 3). This method incorporates the collection of areal rather than point data to evaluate the mosaic surface as a whole and without making contact with it.

The official color-difference formula is currently CIEDE2000, which is jointly recommended by the
International Commission on Illumination and the International Organization for Standardization (ISO). However, many users continue being most familiar with the CIE $1976 L^{*} a * b *$ (CIELAB) color-difference formula and coordinates $[27,28]$. For this reason, both CIELAB and CIEDE2000 results have been provided.

The $X, Y, Z$ values obtained from the LumiCam $^{\circledR}$ were adjusted to the levels of illumination at the time of the measurement through the white reference from the $\mathrm{X}$-Rite ColorChecker ${ }^{\circledR}$ panel. In addition, the reference illuminant (D100 CIE) has spectral characteristics very similar to the indirect natural light [29].

The $L^{*}, a^{*}, b^{*}$ coordinates were calculated from the tri-stimuli values $(X, Y, Z)$ for each pixel of the image taken by the LumiCam ${ }^{\circledR}$ camera and for each cleaning stage $\left(\mathrm{m}_{0}, \mathrm{~m}_{1}\right.$ and $\left.\mathrm{m}_{2}\right)$, as recommended by the CIE1976 $\left(L^{*} a^{*} b^{*}\right)$ color space standard.

The data resulting from each pixel were: $L^{*} a^{*} b^{*}\left(\mathrm{~m}_{0}\right)$ corresponding to a surface with a 6-week deposit layer; $L^{*} a^{*} b^{\prime}\left(\mathrm{m}_{1}\right)$ from the same surface after dry cleaning; and $L^{*} a^{*} b^{*}\left(\mathrm{~m}_{2}\right)$ after the wet cleaning. The chroma $\left(C^{*}{ }_{\mathrm{ab}}\right)$ was calculated from those coordinates as follows:

$$
C_{a b}^{*}=\sqrt{a^{* 2}+b^{* 2}}
$$

And in the same way, the hue angle $h_{\mathrm{ab}}$ :

$$
h_{a b}=\tan ^{-1}\left(\frac{b^{*}}{a^{*}}\right)
$$

Both variables related to each cleaning process of the mosaic $\left(\mathrm{m}_{0}, \mathrm{~m}_{1}\right.$ and $\left.\mathrm{m}_{2}\right)$, resulting in $C^{*}{ }_{\mathrm{ab}(\mathrm{m} 0)}, C^{*}{ }_{\mathrm{ab}(\mathrm{m} 1)}$ and $C^{*}{ }_{\mathrm{ab}(\mathrm{m} 2)}$ for the chroma values, and $h_{\mathrm{ab}(\mathrm{m} 0),} h_{\mathrm{ab}(\mathrm{m} 1)}$ and $h_{\mathrm{ab}(\mathrm{m} 2)}$ for the hue angle values.

The formula CIEDE2000 is the official notation for colour-difference [30], and has been used to determine the lightness $L^{\prime}$, chroma $C^{\prime}$ and colour differences $\Delta E_{00}$ comparing $\mathrm{m}_{0}$ with $\mathrm{m}_{1}$ and $\mathrm{m}_{2}$ :

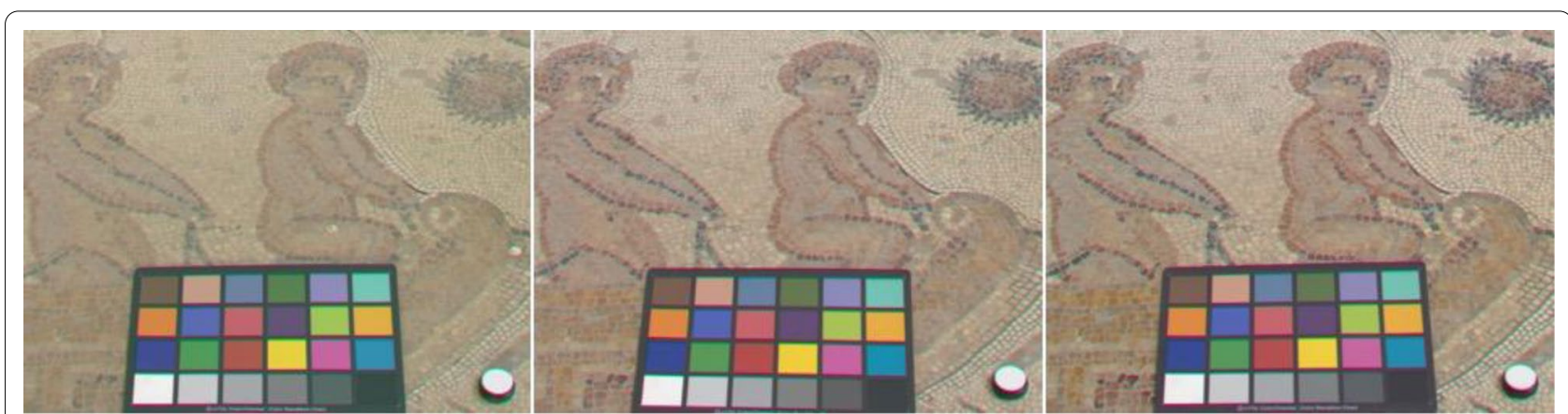

Fig. $3 R G B$ images that show the evolution of the cleaning process: dirty with 6 weeks' deposits $R G B \mathrm{~m}_{0}$ (left), after being cleaned by dry means $R G B \mathrm{~m}_{1}$ (middle) and by wet means $R G B \mathrm{~m}_{2}$ (right). Area: $500 \mathrm{~mm} \times 510 \mathrm{~mm}$ 


$$
\Delta E_{00(n)}=\left[\left(\frac{\Delta L_{(n)}^{\prime}}{k_{L(n)} S_{L(n)}}\right)^{2}+\left(\frac{\Delta C_{(n)}^{\prime}}{k_{C(n)} S_{C(n)}}\right)^{2}\left(\frac{\Delta H_{(n)}^{\prime}}{k_{H(n)} S_{H(n)}}\right)^{2}+R_{T(n)}\left(\frac{\Delta C_{(n)}^{\prime}}{k_{C(n)} S_{C(n)}}\right)\left(\frac{\Delta H_{(n)}^{\prime}}{k_{H(n)} S_{H(n)}}\right)\right]^{\frac{1}{2}}
$$

The differences in lightness $\left(\Delta L^{\prime}\right)$, chroma $\left(\Delta C^{\prime}\right)$ and hue $\left(\Delta H^{\prime}\right)$ have allowed calculating the chromatic shift between two areas $\left(\Delta E_{00}\right)$, on the grounds of the following combinations regarding the cleaning process:

- $n=1 \rightarrow$ dry cleaning $\left(\mathrm{m}_{1}\right)$ is compared with a dirty surface $\left(\mathrm{m}_{0}\right)$ in this way:

$$
\begin{aligned}
\Delta L_{(1)}^{\prime} & =L_{\left(m_{1}\right)}^{\prime}-L_{\left(m_{0}\right)}^{\prime} \\
\Delta C_{(1)}^{\prime} & =C_{\left(m_{1}\right)}^{\prime}-C_{\left(m_{0}\right)}^{\prime} \\
\Delta H_{(1)}^{\prime} & =\left[2\left(C_{\left(m_{1}\right)}^{\prime} C_{\left(m_{0}\right)}^{\prime}\right)\right] \sin \left(\frac{1}{2} \Delta h^{\prime}\right)
\end{aligned}
$$

- $n=2 \rightarrow$ wet cleaning $\left(\mathrm{m}_{2}\right)$ is compared with a dirty surface $\left(\mathrm{m}_{0}\right)$ as follows:

$$
\begin{aligned}
\Delta L_{(2)}^{\prime} & =L_{\left(m_{2}\right)}^{\prime}-L_{\left(m_{0}\right)}^{\prime} \\
\Delta C_{(2)}^{\prime} & =C_{\left(m_{2}\right)}^{\prime}-C_{\left(m_{0}\right)}^{\prime} \\
\Delta H_{(2)}^{\prime} & =\left[2\left(C_{\left(m_{2}\right)}^{\prime} C_{\left(m_{0}\right)}^{\prime}\right)\right] \sin \left(\frac{1}{2} \Delta h^{\prime}\right)
\end{aligned}
$$

The parametric weighting factors are $k_{L}, k_{c}$ and $k_{h}$, and for the reference conditions of this case, are considered equal to 1 according to the CIE 101-1993 standard [26]. The weighting functions $\mathrm{S}_{L}, \mathrm{~S}_{C}, \mathrm{~S}_{H}$ and $\mathrm{R}_{T}$ were acquired from the calculation of $\Delta E_{00}$ by the CIEDE2000 color-difference formula [30].

\section{Colorimetric study of specific tesserae}

A representative area of the ornamental floor $(500 \mathrm{~mm} \times 510 \mathrm{~mm}$ ) was chosen to undertake the colorimetric study of specific tesserae, with particular chromatic characteristics. This has permitted a more detailed assessment on the color performance of the mosaic during the cleaning process.

Fifty pixels of tesserae of the same color were selected from the image of the mosaic obtained with the Lumi$\mathrm{Cam}^{\circledR}$ after wet cleaning $\left(\mathrm{m}_{2}\right)$, when the colors could be better appreciated. The mean XYZ value was calculated from the $\mathrm{XYZ}$ values of the pixels measured by the LumiCam $^{\circledR}$. On the other hand, CIELAB L*a"b* values were obtained from the XYZ ones and the color difference $\left(\Delta E_{\text {tessera }}\right)$ in relation to the mean was calculated for each tessera. The tesserae were grouped based on their color (white, ochre, brown, black and grey) by means of MatLab ${ }^{\circledR}$, which was programmed to determine $\Delta E_{\text {tessera }}$ CIELAB $\leq 3$ [31]. The color groups were named after comparing the mean values with colors of the $x$-rite ColorChecker $^{\circledR}$. Figure 4 highlights the brown, white and ochre tesserae grouped by MatLab ${ }^{\circledR}$ from the same area of the mosaic shown in Fig. 3.

With the purpose of determining the chromatic changes on these groups of tesserae after each cleaning stage $\left(\mathrm{m}_{0}, \mathrm{~m}_{1}\right.$ and $\left.\mathrm{m}_{2}\right)$, the chroma $C^{*}$ ab , hue angle $h_{\mathrm{ab}}$ and lightness $L^{*}$ values were calculated based on the standard CIE1976, corresponding to the CIELAB color space, as was done previously for the whole section of the mosaic. To complete this analysis, the color difference $\Delta E_{00}$ was also defined by CIEDE2000 ( $\Delta E_{00(\mathrm{n}) \text { wh }}, \Delta E_{00(\mathrm{n}) \text { oc }}, \Delta E_{00(\mathrm{n})}$ br, $\Delta E_{00(\mathrm{n}) \mathrm{bk}}$ and $\left.\Delta E_{00(\mathrm{n}) \mathrm{gr}}\right)$, after comparing the cleaning stages $\left(\mathrm{m}_{0}, \mathrm{~m}_{1}\right.$ and $\left.\mathrm{m}_{2}\right)$ in the situations $n=(1,2)$.

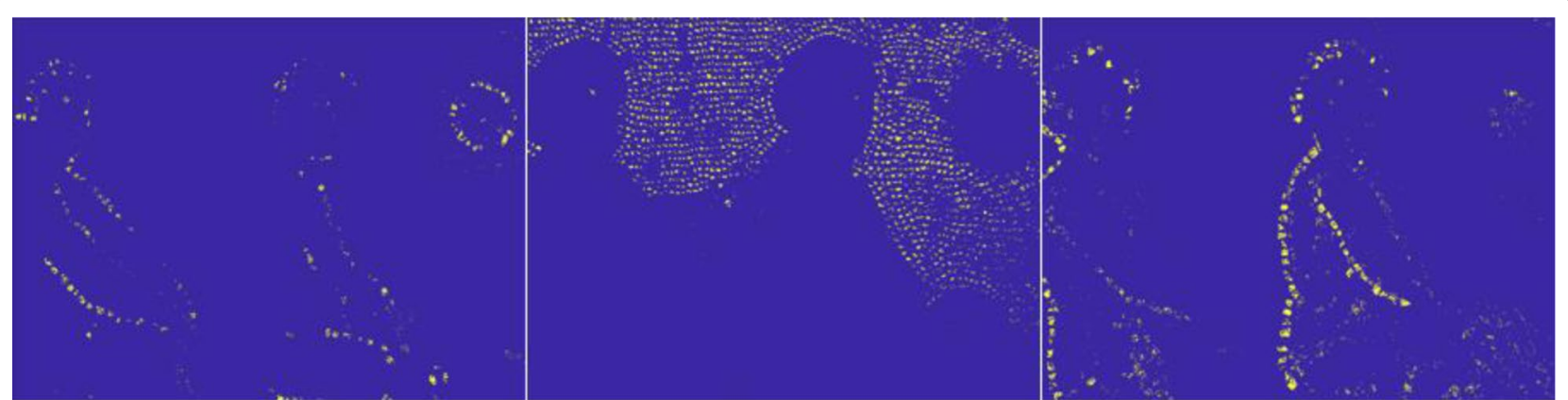

Fig. 4 Selected tesserae for the analysis of chromatic changes after each cleaning stage: 14,219 pixels identified as brown tesserae (left); 25,930 pixels identified as white tesserae (middle); 17,642 pixels identified as ochre tesserae (right). Area: $500 \mathrm{~mm} \times 510 \mathrm{~mm}$ 


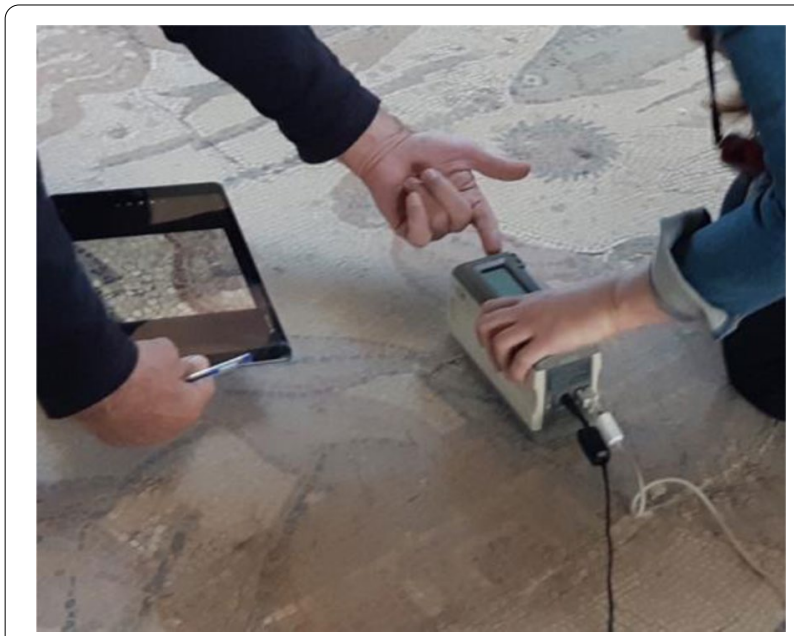

Fig. 5 Measurements taken by the spectrophotometer CM-2600d Konica Minolta ${ }^{\circledR}$ over the selected tesserae of the mosaic

\section{Analysis of reflectance}

The measurements for the analysis of reflectance were taken with a spectrophotometer (CM-2600d Konica Minolta $^{\circledR}$ ) (Fig. 5). This gives absolute reflectance measurements in the visible range (from 380 to $740 \mathrm{~nm}$ in $10 \mathrm{~nm}$ steps). The area of measurement is $8 \mathrm{~mm}$ in diameter. The light source is provided by the three xenon bulbs of the meter, which emit in the visible range. A complete calibration of the instrument was undertaken prior to the analysis by means of the white and black reference checkers provided with the meter.

Six tesserae were selected by their color (two per each): ochre $(1 \mathrm{R}$ and $2 \mathrm{R})$, white $(1 \mathrm{~B}$ and $2 \mathrm{~B})$ and black $(1 \mathrm{~N}$ and $2 \mathrm{~N})$ (Fig. 6). The reflectance measurements $(\rho)$ were taken twice per tessera by placing the instrument directly onto them before cleaning $\left(\rho \mathrm{xV}_{(\mathrm{m} 0)}\right)$, after dry cleaning $\left(\rho \mathrm{xV}_{(\mathrm{m} 1)}\right)$ and after wet cleaning $\left(\rho \mathrm{xV}_{(\mathrm{m} 2)}\right)$, where $x=(1$, 2 ) represents the tesserae numbered with 1 and 2 , and $\mathrm{V}=(\mathrm{R}, \mathrm{N}, \mathrm{B})$ the colors. The spectral difference $\Delta \rho_{(\mathrm{n})}$ regarding each cleaning process $\left(\mathrm{m}_{0}, \mathrm{~m}_{1}, \mathrm{~m}_{2}\right)$ was calculated by:

$$
\Delta \rho x V_{(n)}=\rho x V_{\left(m_{1} m_{2}\right)}-\rho x V_{\left(m_{0}\right)}
$$

With $n=(1,2)$, previously described in the calculation for the color differences in relation to the cleaning process.

The reflectance values and differences in reflectance provided detailed information about the spectral characteristics of each color. It has also been useful for understanding how deposits affect specific tesserae spectrally, changing their color, lightness and hue.

\section{Results and discussion \\ Colorimetric changes of the mosaic}

The macroscopic view of the mosaic (Fig. 3) shows that after six weeks there is a lack of contrast and detail, and the outlines become imprecise and the colors disguised.

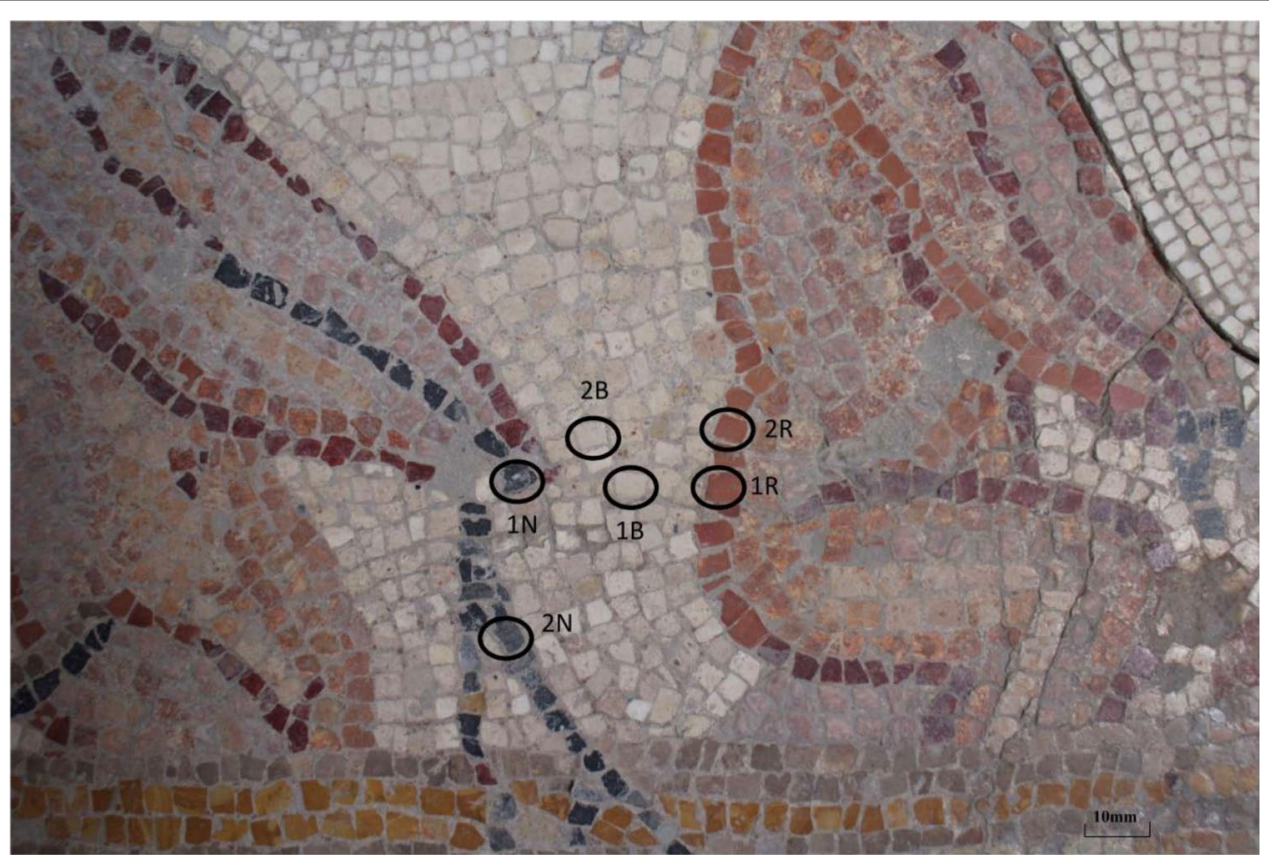

Fig. 6 Spots where the reflectance measurements were taken 


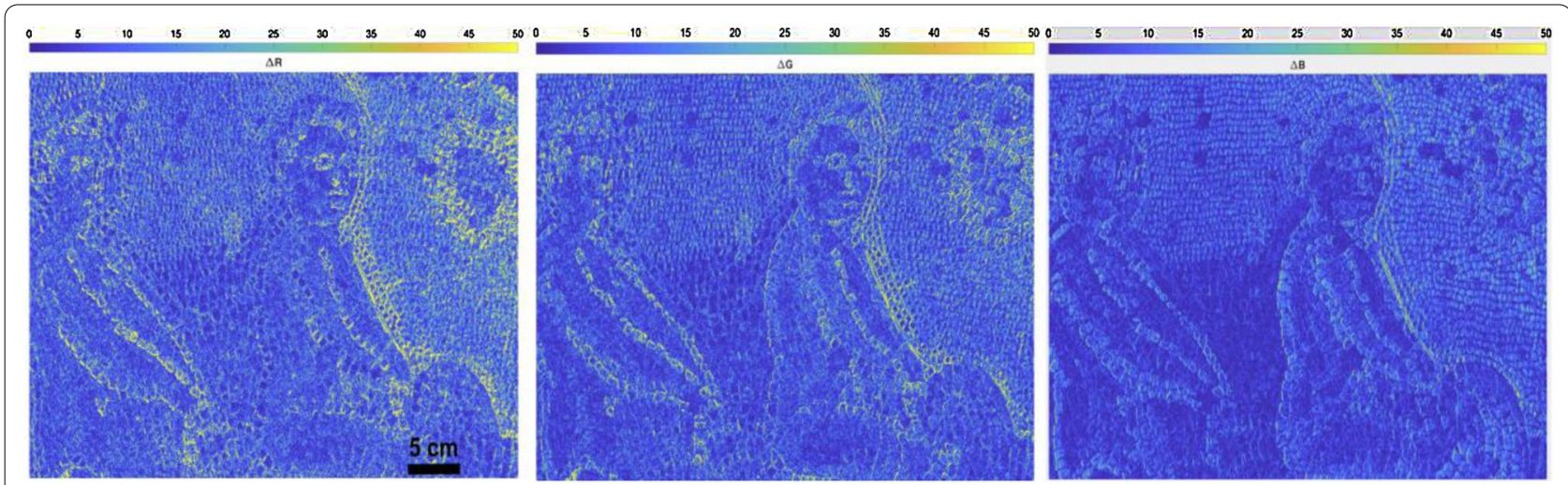

Fig. 7 Heat maps showing the differences in $R, G$ and $B$ values $\left(\Delta R, \Delta G\right.$ and $\Delta B$ ) between a wet cleaned and dirty surface $\left(m_{0}\right.$ and $\left.m_{2}\right)$. The deposits have a greater influence in reds (left) and greens (middle). Area: $500 \mathrm{~mm} \times 510 \mathrm{~mm}$

Table 1 Mean lightness $\left(L^{*}\right)$, chroma $\left(C^{*}{ }_{a b}\right)$ and hue angle $\left(h_{a b}\left({ }^{\circ}\right)\right)$ for the white (wh), ochre (oc) and brown (br) tesserae before and after the cleaning process $\left(m_{0}=\right.$ dirty, $m_{1}=$ dry cleaning, $\mathrm{m}_{2}=$ wet cleaning), according to the CIELAB color space (CIE $\left.1976 L^{*} a^{*} b^{*}\right)$

\begin{tabular}{lllll}
\hline Tesserae & Cleaning stage & $\overline{L^{*}}(\sigma)$ & $\overline{C_{a b}^{*}}(\sigma)$ & $\overline{h_{a b}}(0)(\sigma)$ \\
\hline White (wh) & $\mathrm{m}_{0}$ & $74.32(2.82)$ & $17.44(3.94)$ & $103.65(21.11)$ \\
& $m_{1}$ & $76.84(3.20)$ & $14.29(3.93)$ & $98.34(25.65)$ \\
& $m_{2}$ & $79.48(1.93)$ & $11.38(1.90)$ & $97.83(12.21)$ \\
Ochre (oc) & $m_{0}$ & $57.80(3.22)$ & $17.13(3.86)$ & $72.11(23.00)$ \\
& $m_{1}$ & $54.99(3.23)$ & $18.94(4.68)$ & $54.76(23.74)$ \\
& $m_{2}$ & $52.50(2.01)$ & $22.63(2.02)$ & $47.00(5.33)$ \\
Brown (br) & $m_{0}$ & $49.03(7.18)$ & $13.60(4.72)$ & $90.86(34.03)$ \\
& $m_{1}$ & $45.53(5.53)$ & $13.65(6.02)$ & $59.74(46.77)$ \\
& $m_{2}$ & $43.95(1.83)$ & $13.17(2.00)$ & $42.21(11.13)$ \\
\hline
\end{tabular}

б: Standard deviation

According to Grossi and Brimblecombe [17], when design details or lines are covered, it is most likely to cause adverse responses from the public.

The removal of deposits improved the appreciation of the mosaic, making the colors sharper and shapes and volumes more defined. The surface after both the dry and wet cleaning looked lighter and the colors could be fully perceived. The change, translated into objective values, is represented in Fig. 7.

\section{Colorimetric study of specific tesserae}

The study of the colors of the tesserae in relation to the cleaning process has provided three results. Firstly, a mean percentage of the CIELAB values $\left(L^{*}, C^{*}\right.$ ab and $\left.h_{\mathrm{ab}}\right)$ corresponding to each studied color; secondly, the graphic representation of the color performance for each group of tesserae; and finally, a mean percentage of the
CIEDE2000 color-difference values between cleaning stages $\left(\Delta E_{00}\right)$.

\section{CIELAB values}

Table 1 shows the mean value of the CIELAB chromatic coordinates of lightness $\left(L^{\prime}\right)$, chroma $\left(C_{\mathrm{ab}}^{\prime}\right)$ and hue angle $\left(h_{\mathrm{ab}}\right)$ for the white (wh), ochre (oc) and brown (br) tesserae at each cleaning stage.

The CIELAB analysis of the pixels from the white tesserae (wh) show that lightness $\left(L^{*}\right.$ wh $)$ increased an average of $3.02 \%\left(\sigma_{\mathrm{L} 1 \text { wh }}=0.015\right)$ after the dry cleaning $\left(\mathrm{m}_{1}\right)$ in relation to the dirty surface $\left(\mathrm{m}_{0}\right)$, and $6.47 \%$ $\left(\sigma_{\mathrm{L} 2 \text { _wh }}=0.034\right)$ after the wet cleaning $\left(\mathrm{m}_{2}\right)$ in relation to $\mathrm{m}_{0}$. Alternately, the mean chroma $\left(C_{\text {ab_wh }}^{*}\right)$ at $\mathrm{m}_{1}$ was about $18.81 \%\left(\sigma_{\mathrm{C} 1 \_w h}=0.12\right)$ lower than before any type of cleaning $\left(\mathrm{m}_{0}\right)$, and decreased $34.72 \%\left(\sigma_{\mathrm{C} 2 \_w h}=0.12\right)$ at $\mathrm{m}_{2}$ if compared with $\mathrm{m}_{0}$.

On the contrary, the lightness $\left(L^{*}{ }_{\text {oc }}\right)$ of the ochre tesserae (oc) decreased $4.86 \%\left(\sigma_{\mathrm{L} 1 \_o c}=0.039\right)$ at $\mathrm{m}_{1}$, and $9.16 \%\left(\sigma_{\mathrm{L} 2 \_o c}=0.072\right)$ at $\mathrm{m}_{2}$, both in relation to $\mathrm{m}_{0}$. Chroma $\left(C^{*}\right.$ ab oc $)$ was higher at both stages, $\mathrm{m}_{1}$ and $\mathrm{m}_{2}$, in relation to $\mathrm{m}_{0}$, specifically $10.57 \%\left(\sigma_{\mathrm{C1} \_o c}=0.40\right)$ in the first case and $32.07 \%\left(\sigma_{\mathrm{C} 2 \_ \text {oc }}=0.36\right)$ in the second one.

Finally, the mean lightness $\left(L^{*}\right.$ br $)$ of the brown tesserae presented a reduction of $7.15 \%\left(\sigma_{\mathrm{L} 1 \_b r}=0.08\right)$ at $\mathrm{m}_{1}$ and $10.37 \%\left(\sigma_{\mathrm{L} 2 \_b r}=0.14\right)$ at $\mathrm{m}_{2}$, both in relation to $\mathrm{m}_{0}$. The difference in chroma $\left(C_{\text {ab br }}^{\prime}\right)$ between $\mathrm{m}_{1}$ and $\mathrm{m}_{0}$ was $0.33 \%\left(\sigma_{\mathrm{C} 1 \_ \text {br }}=0.53\right)$ and $3.18 \%\left(\sigma_{\mathrm{C} 2 \_ \text {br }}=0.40\right)$ between $\mathrm{m}_{2}$ and $\mathrm{m}_{0}$.

On the other hand, the obtained hue angle values $\left(h_{\mathrm{ab}}\right)$ indicate that the cleaning process of the mosaic modifies the angular position in the quadrants that represent the hue, making the colors of the tesserae have a more yellow aspect. This change already takes place after the dry cleaning but in a very subtle way. 


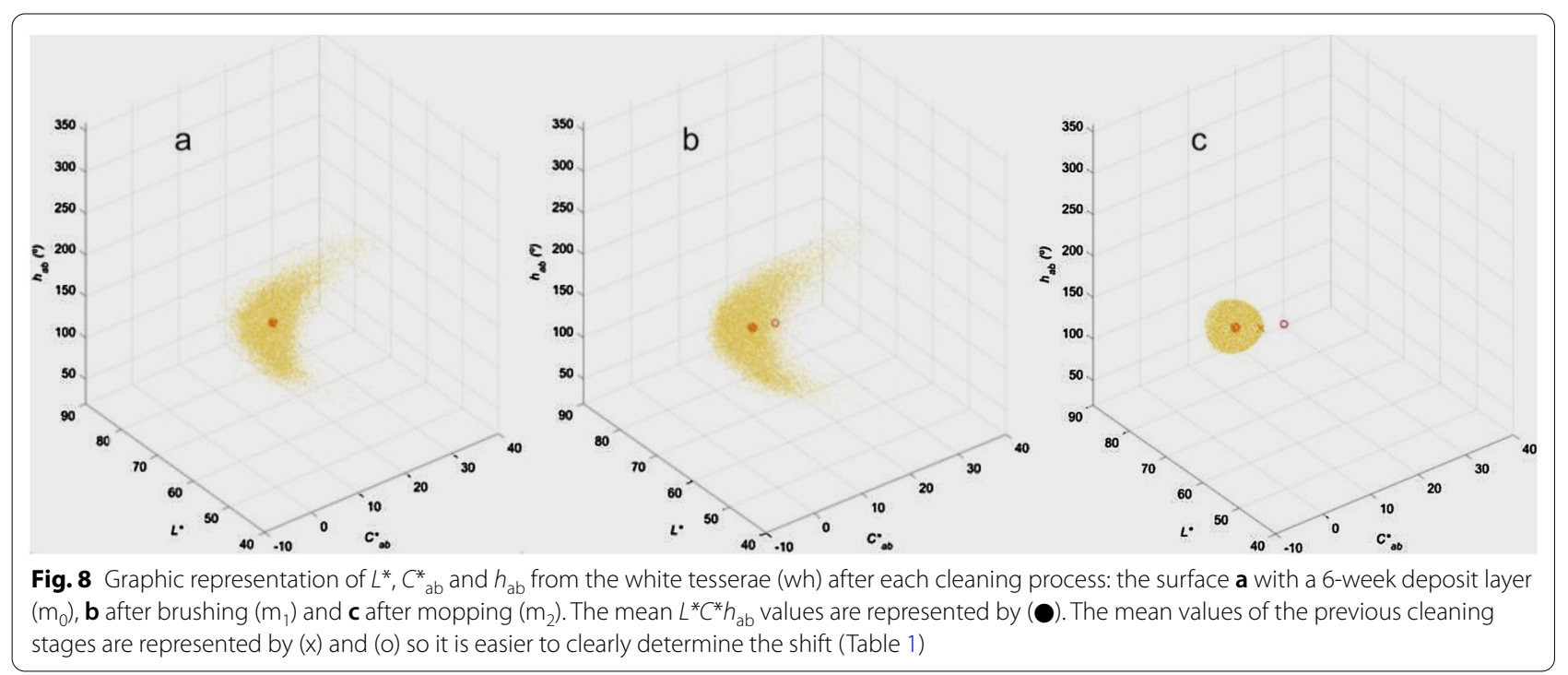

\section{Chromatic representation}

A graphic representation of chroma $\left(C^{*}{ }_{a b}\right)$, lightness $\left(L^{*}\right)$ and hue angle $\left(h_{\mathrm{ab}}\right)$ of the white, ochre and brown tesserae has helped to visualize how their chromatic characteristics changed during the cleaning process so that decisions about the conservation and presentation of the site can be objectively taken.

In the case of the white tesserae, there was a wide chromatic diversity when the mosaic was dirty (Fig. 8a) and after the dry cleaning (Fig. 8b), but after the wet cleaning (Fig. 8c) it is possible to see that the coordinates moved closer to each other.
Similarly, there was a widespread chromatic diversity among ochre tesserae before any cleaning (Fig. 9a). The chromatic characteristics became progressively closer after the dry (Fig. 9b) and wet cleaning (Fig. 9c).

A comparable chromatic performance was found for the brown tesserae. There was a considerable dissimilarity among these when the mosaic was dirty (Fig. 10a), which persisted even after the dry cleaning (Fig. 10b), but this changed after the wet cleaning (Fig. 10c) where resultant colour of the tesserae were restricted to a smaller chromatic area.

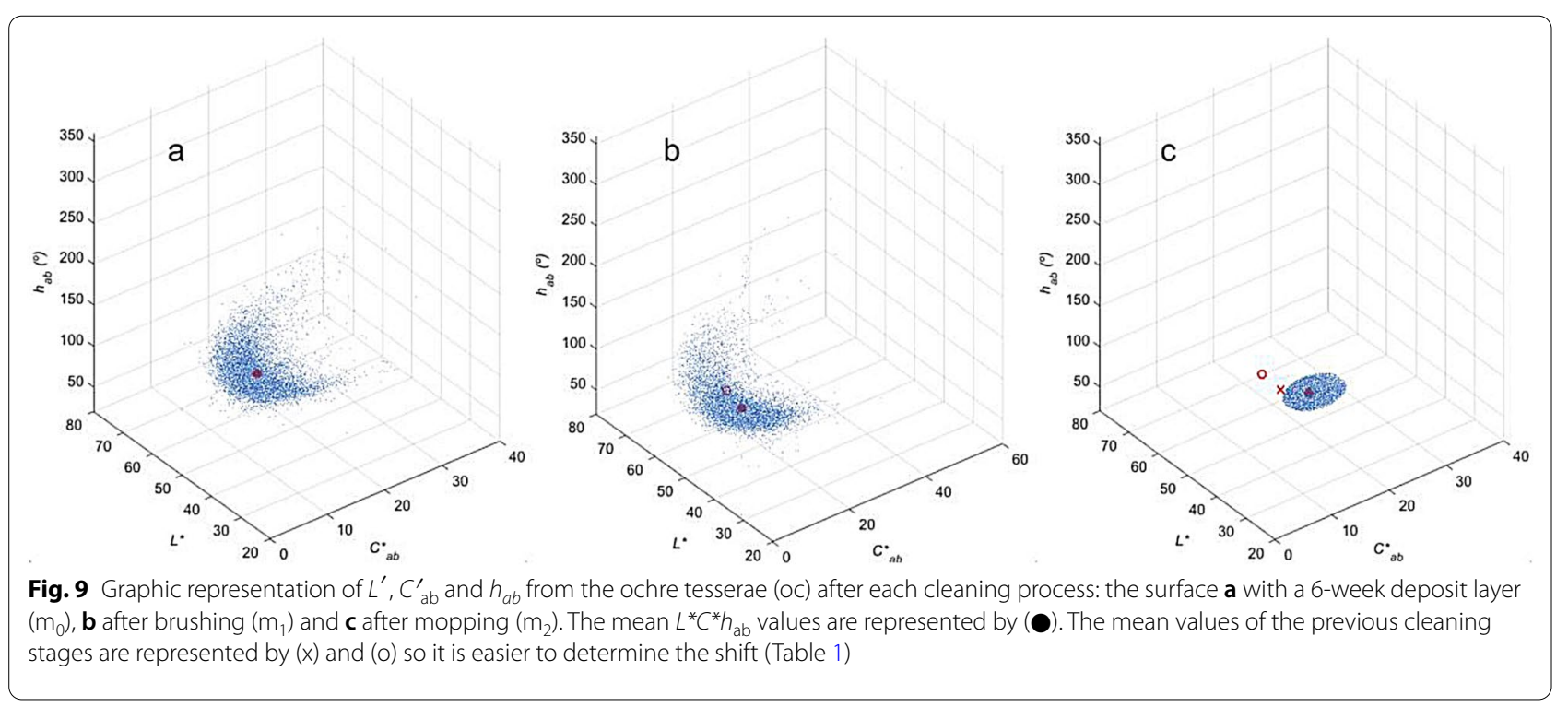




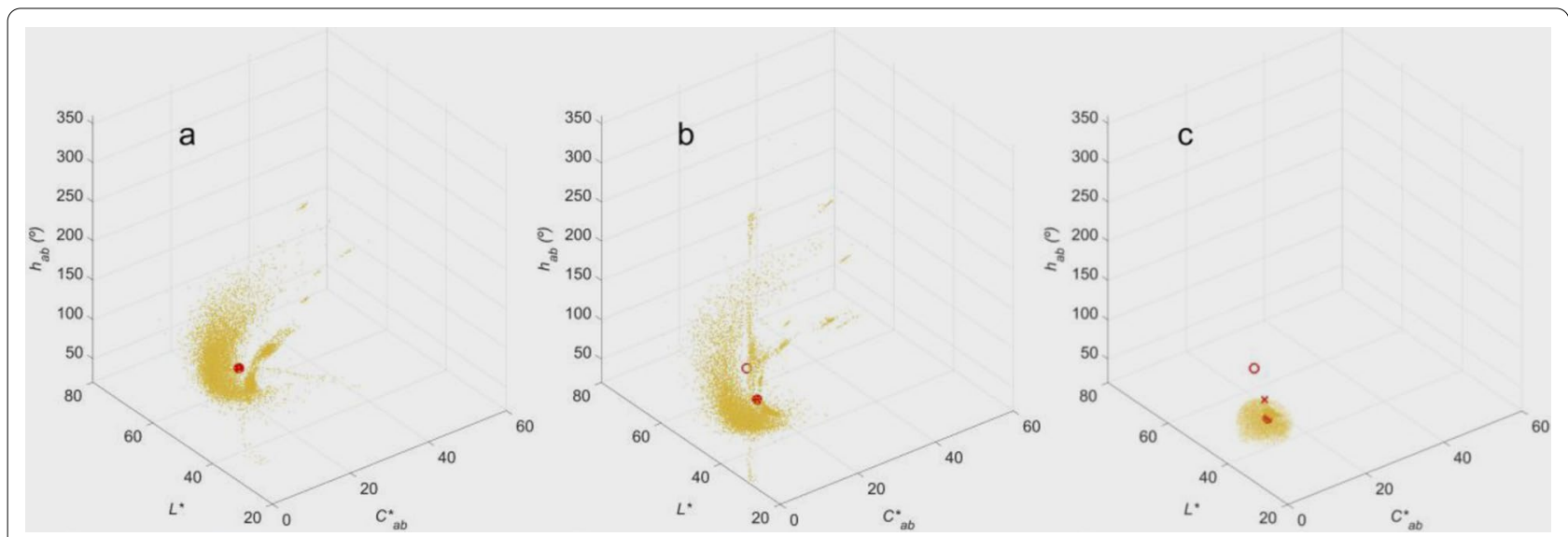

Fig. 10 Graphic representation of $L^{*}, C^{*}{ }_{\mathrm{ab}}$ and $h_{\mathrm{ab}}$ from the brown tesserae (br) after each cleaning process: the surface a with a 6-week deposit layer $\left(m_{0}\right)$, b after brushing $\left(m_{1}\right)$ and $\mathbf{c}$ after mopping $\left(m_{2}\right)$. The mean $L^{*} C^{*} h_{a b}$ values are represented by $(\boldsymbol{O})$. The mean values of the previous cleaning stages are represented by $(\mathrm{x})$ and $(\mathrm{o})$ so it is easier to clearly determine the shift (Table 1)

Table 2 Mean differences of lightness $\left(\Delta L^{\prime}\right)$, chroma $\left(\Delta C^{\prime}\right)$, hue $\left(\Delta H^{\prime}\right)$ and color $\left(\Delta E_{00}\right)$ along the cleaning processes for the white (wh), ochre (oc) and brown (br) tesserae according to the standard CIEDE2000

\begin{tabular}{llcccc}
\hline Tesserae & $(n)$ & $\Delta \overline{\mathrm{L}^{\prime}}$ & $\Delta \overline{\mathrm{C}^{\prime}}$ & $\Delta \overline{\mathrm{H}^{\prime}}$ & $\Delta \overline{\mathrm{E}_{00}}$ \\
\hline White (wh) & $1 \Longrightarrow\left(m_{1}-m_{0}\right)$ & 2.52 & -3.21 & -1.99 & 4.63 \\
& $2 \Longrightarrow\left(m_{2}-m_{0}\right)$ & 5.16 & -6.93 & -1.63 & 7.63 \\
Ochre (oc) & $1 \Longrightarrow\left(m_{1}-m_{0}\right)$ & -2.81 & 3.24 & -6.63 & 7.57 \\
& $2 \Longrightarrow\left(m_{2}-m_{0}\right)$ & -5.29 & 7.67 & -9.91 & 11.70 \\
Brown (br) & $1 \Longrightarrow\left(m_{1}-m_{0}\right)$ & -3.51 & 1.81 & -9.61 & 11.66 \\
& $2 \Longrightarrow\left(m_{2}-m_{0}\right)$ & -5.08 & 1.50 & -13.48 & 15.03
\end{tabular}

(n): Combinations for the calculation of $\Delta$ depending on the cleaning stage. LumiCam ${ }^{\circledR}$ color uniformity $= \pm 0.001$ (average of $10 \times 10$ pixels)

\section{CIEDE2000 color difference}

After the study of mean differences of lightness $\left(\Delta L^{\prime}\right)$, chroma $(\Delta C)$ and hue $\left(\Delta H^{\prime}\right)$ for the white, ochre and brown tesserae according to the CIEDE2000 standard, it is possible to say that the cleaning process clearly affects these values (Table 2). Lightness decreases for the ochre and brown tesserae and increases for the white ones after the deposits are removed, particularly with the wet cleaning. There is also a significant hue difference for the ochre and the brown tesserae, -9.91 and -13.48 respectively in $n=2$. The difference in chroma is also influenced by the cleaning process, especially for the white and ochre tesserae, at -6.93 and 7.67 respectively for $n=2$.

Considering the illumination conditions and colors of the case study, the threshold for color difference perception has been established as $\Delta E_{00} \approx 3$ (JND) [31-33]. As the resulting color difference values $\left(\Delta E_{00}\right)$ for both dry and wet cleaning are over this threshold (Fig. 11), the change is perceptible by the naked eye. For example,

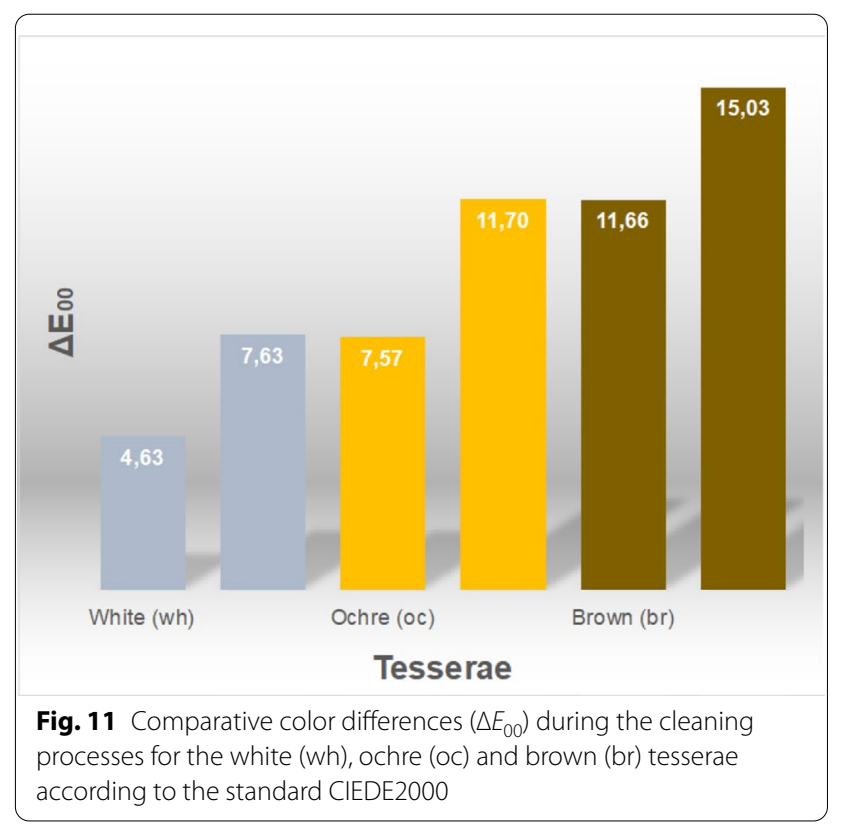

brown tesserae have a minimum value of 11.66 and a maximum of 15.03 , which corresponds to five times the estimated JND.

\section{Analysis of reflectance}

Figure 12 shows the spectral reflectance $(\rho)$ of the ochre $(2 \mathrm{R})$, white $(2 \mathrm{~B})$ and black $(2 \mathrm{~N})$ tesserae, in addition to the spectral difference $\left(\Delta \rho_{(n)}\right)$ for each cleaning process (i.e. $\mathrm{m}_{0}$ compared with $\mathrm{m}_{1}$ and $\mathrm{m}_{2}$ ).

The spectral curves of the ochre tesserae after the two types of cleaning $\left(\rho_{2 R} m_{2}, \rho_{2 R} m_{1}\right)$ show a more standard ochre colour than the one before the cleaning $\left(\rho_{2 R} \mathrm{~m}_{0}\right)$. 

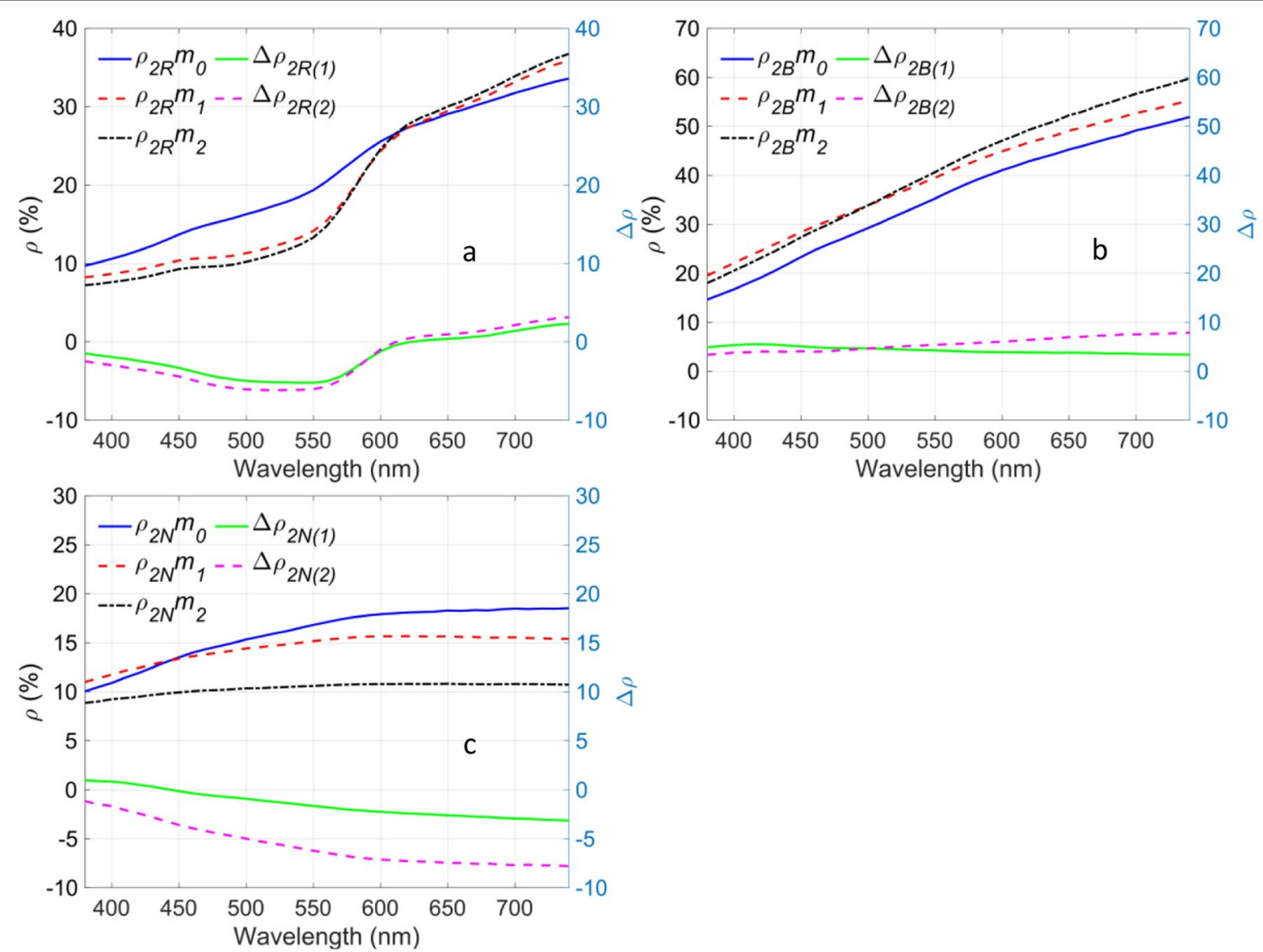

Fig. 12 Graphs showing the spectral reflectance $\left(\rho m_{0} \rho m_{1}\right.$ and $\left.\rho m_{2}\right)$ and spectral differences $\left(\Delta \rho_{(1)}, \Delta \rho_{(2)}\right)$ of the selected tesserae after each cleaning process $\left(m_{0} m_{1}\right.$ and $\left.m_{2}\right)$ : a ochre $(2 R)$, $\mathbf{b}$ white $(2 B)$ and $\mathbf{c}$ black $(2 N)$ tesserae

The spectral differences $\left(\Delta \rho_{2 R(1)}, \Delta \rho_{2 R(2)}\right)$ also show an important shift in the wavelengths between 480 and $550 \mathrm{~nm}$; blue and green hues are minimised, leaving the yellow, orange and red as the most significant ones after the cleaning.

Both dry and wet cleaning $\left(\rho_{2 B m 2}, \rho_{2 B m 1}\right)$ increases the reflectance of the white tesserae compared to the surface with deposits of 6 weeks $\left(\rho_{2 \mathrm{Bm} 0}\right)$. In addition, the spectral curves are similar at the three stages apart from a small decrease in the blue area and an increase in the red one after the wet cleaning $\left(\Delta \rho_{2 B(2)}\right)$.
In the case of black tesserae, the removal of deposits by dry cleaning $\left(\rho_{2 \mathrm{Nm} 1}\right)$ supposes a homogenization of the spectral profile, but the reflectance is higher than the value obtained after the wet cleaning $\left(\rho_{2 \mathrm{Nm} 2}\right)$ where it remains at $10 \%$ almost constantly (which strictly corresponds to a black colour). The deposits on the surface $\left(\rho_{2 \mathrm{~N}} \mathrm{~m}_{0}\right)$ made the spectral curve increase from the area corresponding to the yellows and the reds. The spectral differences are noticeable after the two cleaning stages in relation to the dirty surface $\left(\rho_{2 \mathrm{Nm} 0}\right)$, but the difference is even greater after the wet cleaning $\left(\Delta \rho_{2 \mathrm{~N}(2)}\right)$.

Table 3 Mean reflectance values (\%) of ochre (1R and $2 \mathrm{R})$, white ( $1 \mathrm{~B}$ and $2 \mathrm{~B})$ and black tesserae $(1 \mathrm{~N}$ and $2 \mathrm{~N})$ before cleaning $\left(\mathrm{m}_{0}\right)$ and after dry $\left(m_{1}\right)$ and wet cleaning $\left(m_{2}\right)$. CM-2600d Konica Minolta ${ }^{\circledR}$ standard deviation within $0.1 \%$

\begin{tabular}{lllllll}
\hline & $1 \overline{\mathrm{R}}$ & $2 \overline{\mathrm{R}}$ & $1 \overline{\mathrm{B}}$ & $2 \overline{\mathrm{B}}$ & $1 \overline{\mathrm{N}}$ & $2 \overline{\mathrm{N}}$ \\
\hline Dirty $\left(\mathrm{m}_{0}\right)$ & 31.19 & 32.36 & 51.54 & 52.87 & 34.92 & 24.04 \\
Dry cleaning $\left(\mathrm{m}_{1}\right)$ & 29.87 & 29.64 & 57.35 & 59.36 & 15.59 & 21.83 \\
Wet cleaning $\left(\mathrm{m}_{2}\right)$ & 29.25 & 29.29 & 43.21 & 61.35 & 15.30 & 15.63 \\
\hline
\end{tabular}


These changes can also be observed in Table 3, which depicts the quantification of the mean reflectance values. In the case of the ochre tesserae, there was a decrease in reflectance of $1.66 \%$ and $2.22 \%$ if the dirty stage $\left(\mathrm{m}_{0}\right)$ is compared respectively with the dry cleaning $\left(\mathrm{m}_{1}\right)$ and the wet one $\left(\mathrm{m}_{2}\right)$. The reflectance similarly decreased in the black tesserae $(9.13 \%$ and $11.89 \%)$ and the change after the wet cleaning is noticeable by the naked eye [2]. However, there was an increase of around $2.9 \%$ and $16 \%$ in the case of the white tesserae. Table 3 shows that the reflectance of the tessera 2B decreased after the wet cleaning process $\left(\mathrm{m}_{2}\right)$. This variation in the trend might be due to a displacement of the spectrophotometer when the measurement was taken, or the result of the cleaning itself because a dust particle could have been moved to the area resulting in a not completely white tessera.

\section{Conclusions}

This research has shown that all tesserae became closer to their original color and spectral characteristics after the cleaning of a 6-week dust deposit layer. The CIEDE2000 color difference values indicate that the changes are perceptible by the naked eye, particularly after the wet procedure. The excessive accumulation of dust on an ornamental surface could enhance an incorrect interpretation and deficient appreciation overall. A feeling of lack of care might also contribute to a reduction in the visitors' experience.

The results depict that the deposition tends to yellow; this agrees with the analysis undertaken in Complutum by previous studies [34] where deposition was chemically characterized and identified as mineral dust. Especially important are the color differences of the brown tesserae before and after being cleaned $\left(\Delta E_{00}=15.03\right.$ at $\left.\mathrm{n}=2\right)$. The contrast of a dark tile covered by lighter deposits makes it more probable for visitors to perceive the mosaic as dirty [17].

The deposits have a higher reflectance than the white tesserae, but lower than ochre or black, and the removal of dust makes the surface look brighter in the first case and darker in the latter two. According to Bellan, Salmon and Cass [15], a loss in reflectance of more than 10\% corresponds to a visible change, as was the case of the black tesserae. However, the 35\% threshold for significant adverse reactions from the public [16] is not reached at any point.

The yellowish general appearance after 6 weeks disappears partially after dry cleaning. This system could be sufficient if repeated more frequently and if the whole site is treated all together, so a direct comparison between cleaned and uncleaned areas is not possible. However, the surface with a 6-week dust layer presents a wide dissimilarity in chromatic characteristics among tesserae of the same color; their homogenization is obtained after the wet cleaning process. Therefore, the subtle artistic aspects and vivid colors that are distinctive characteristics of a Roman mosaic of such quality are only fully recovered after a wet cleaning.

The cleaning process should be justified for each specific case attending to not only conservation criteria but also the aspect. The frequency of cleaning in relation to the general appearance could be established depending on the chromatic shifts and the color difference values of a group of tesserae monitored periodically. In this case, brown tesserae offer the worst results after 6 weeks $\left(\Delta E_{00}=11.66\right)$ so these should be taken as a reference. Nevertheless, it is difficult to perceive the mosaic as dirty if there is not a direct comparison between cleaned and uncleaned surfaces [7]. Future research could investigate how uncomfortable observers feel about the deposits, as Lithgow et al. [12] did for historic interiors or Brimblecombe and Grossi [9] for blackening at buildings, so that the publicly acceptable levels of dirt can be determined in the case of mosaics.

\section{Acknowledgements}

We would like to thank Prof. Joaquín Barrio, Director of the Service for the Conservation, Restoration and Scientific Studies of Archaeological Heritage at Universidad Autónoma de Madrid, and Dr. Sebastián Rascón, municipal archaeologist of Alcalá de Henares, for their support and for allowing us to work in Complutum.

\section{Authors' contributions}

State of art and research questions: CCB. Research design: SMP, CCB. Data collection: SMP, DVM, AAFB, CCB. Data analysis: SMP, DVM, AAFB. Interpretation of the results: SMP, DVM, AAFB, CCB. Writing and edition: SMP, CCB. All authors read and approved the final manuscript.

\section{Funding}

This research did not receive any specific grant from funding agencies in the public, commercial, or not-for-profit sectors.

\section{Availability of data and materials}

The data supporting the findings is presented in the paper in the form of tables and figures.

\section{Declarations}

Competing interests

We have no conflicts of interest to disclose.

\section{Author details \\ ${ }^{1}$ Service for the Conservation, Restoration and Scientific Studies of Archaeo- logical Heritage (SECYR), Facultad de Filosofía y Letras, Universidad Autónoma de Madrid, Módulo X Planta Baja, 28049 Madrid, Spain. ${ }^{2}$ Optics Department, Universidad Complutense de Madrid, C/Arcos de Jalón 118, 28037 Madrid, Spain.}

Received: 12 December 2020 Accepted: 11 March 2021 Published online: 31 March 2021 


\section{References}

1. Brimblecombe P. Environmental and architectural stone. In: Siegesmund S, Snethlage R, editors. Stone in architecture. Berlin: Springer; 2011. p. 317-46.

2. Grau-Bové J, Strlič M. Fine particulate matter in indoor cultural heritage: a literature review. Heritage Science. 2013;1:8. https://doi.org/10.1186/ 2050-7445-1-8.

3. Tétreault J. Airborne pollutants in museums, galleries and archives: risk assessment, control strategies, and preservation management. Otawa: Canadian Conservation Institute; 2003.

4. Instituto Centrale per il Restauro and Ministero per i Beni e le Attività Culturali. Le Coperture delle aree archeologiche. Museo aperto. Rome: Gangemi Editore; 2006.

5. Cabello Briones $C$. The effects of open shelters on the preservation of limestone remains at archaeological sites. Oxford: PhD thesis University of Oxford; 2016.

6. Cabello Briones $\mathrm{C}$, Viles $\mathrm{H}$. An assessment of the role of an open shelter in reducing soiling and microbial growth on the archaeological site of the Bishop's Palace, Witney, England. Conserv Manag Archaeol Sites 2018:20:1. https://doi.org/10.1080/13505033.2018.1430437.

7. Grossi CM. Soling and discolouration. In: Brimblecombe P, editor. Urban pollution and changes to materials and building surfaces. London: Imperial College Press; 2016. p. 127-42

8. Watt J, Hamilton R, Lefevre RA, Ionescu A. Soiling. In: Hamilton R, Kucera V, Tidblad J, Watt J, editors. The effects of air pollution on cultural heritage. Boston: Springer; 2009. p. 105-26.

9. Brimblecombe P, Grossi CM. Aesthetic thresholds and blackening of stone buildings. Sci Total Environ. 2005;349(1-3):175-98. https://doi.org/ 10.1016/j.scitotenv.2005.01.009.

10. Viles HA, Gorbushina A. Soiling and microbial growth on urban roadside limestone; a three year study in Oxford. Engl Build Environ. 2003;38(910):1217-24. https://doi.org/10.1016/S0360-1323(03)00078-7.

11. Gaviño M, Hermosin B, Castillejo M, Ouija M, Rebollar E, Verges-Belmin V Nowik W, Saiz- JC. Black curst removal: the effect of stone yellowing and cleaning strategies. In: Saiz-Jimenez C, editor. Air pollution and cultural heritage. London: Balkema; 2004. p. 239-45.

12. Lithgow $K$, Lloyd H, Brimblecombe P, Hun Yoon $Y$, Thickett D. Managing dust in historic houses - A visitor-conservator interface. In: ICOM-CC 14th Triennial Meeting Preprints (The Hague, 2005). London: James \& James; 2005. p. 662-669.

13. Anaf W, Bencs R, Van Grieken R, Janssens K, De Wael K. Indoor particulate matter in four Belgian heritage sites: case studies on the deposition of dark-colored and hygroscopic particles. Sci Total Environ. 2015;506507:361-8. https://doi.org/10.1016/j.scitotenv.2014.11.018.

14. Dillon C, Golfomitsou S, Ravaioli F, Storey C, Tully C, McArthur G, Lithgow K. A Bottom-up and Mixed-Methods Approach to Understanding Visitors' Perceptions of Dust, Dirt and Cleaning. In: ICOM-CC 18th Triennial Conference Preprints (Copenhagen, 2017). Paris: International Council of Museums; 2017. p. 1-10.

15. Bellan LM, Salmon LG, Cass GR. A Study on the human ability to detect soot deposition onto works of art. Environ Sci Technol. 2000;34(10):194652. https://doi.org/10.1021/es990769f.

16. Watt J, Jarrett D, Hamilton R. Dose-response functions for the soiling of heritage materials due to air pollution exposure. Sci Total Environ. 2008;400(1-3):415-24

17. Grossi CM, Brimblecombe P. Aesthetics of simulated soiling patterns on architecture. Environ Sci Technol. 2004;38(14):3971-6. https://doi.org/10. 1021/es0353762.

18. Hun Yoon Y, Brimblecombe P. Dust at Febrigg Hall. The National Trust View. 2000:32:31-2
19. Cobau AC, Nardi R. Conservation and protection of archaeological mosaics: The case of the Building of the Nile in Zippori. In: Proceedings of the $\mathrm{VI}$ Conference of the International Committee for the Conservation of Mosaic. Mosaics make a site: the conservation in situ of mosaics on archaeological sites (Nicosia, 1996). Rome: ICCROM; 2003. p. 321-340.

20. Stewart J. The Conservation of Mosaics on Archaeological Sites. In Conservation of Cultural Heritage in the Arab Region. Issues in the Conservation and Management of Heritage Sites. Rome: ICCROM; 2013. p. 84-90.

21. Rascón MS. La así llamada casa de Hippolytus: la fundación de los Anios y la schola de una agrupación colegial de la ciudad romana de Complutum. Arch Esp Arqueol. 2007;80:119-52. https://doi.org/10.3989/aespa. 2007.v80.30.

22. Fernández GD. Complutum. II Mosaicos Excavaciones Arqueológicas en España. Madrid: Ministerio de Cultura; 1984

23. Rascón Marqués S, Polo López J, Gómez Pallarés J, Méndez MA. Hippolytvs: estudio de un nuevo mosaico del género de pesca y con inscripción procedente de Complutum, Alcalá de Henares. Madrid Lucentum. 1997:1995-1997(14-16):39-62. https://doi.org/10.14198/LVCENTVM19 95-1997.14-16.032

24. Rodríguez Frade JP. Cubierta para las ruinas arqueológicas de la Casa de Hippolytus, en Complutum. Alcalá de Henares Madrid ConArquitectura. 2003;8:15-28.

25. Rascón MS. La Casa de Hippolytus y la recuperación del Patrimonio Arqueológico de Alcalá de Henares. Boletín de la ANABAD. 2003:50(2):203-17.

26. Arquitectura y Restauración Monumental S.L. Memoria final de las Actuaciones arqueológicas y de conservación y restauración en la Casa de Hippolytus: zona sur, Complutum en Alcalá de Henares. Madrid: Conserjería de Cultura, Turismo y Deporte de la Comunidad de Madrid; 2018.

27. International Commission on Illumination. Parametric Effects in ColourDifference Evaluation (CIE 101:1993); 1993.

28. International Commission on Illumination. Colorimetry (CIE 015:2018); 2018.

29. Knoop M, Weber N, Diakite A. Approach to analyse seasonal and geographical variations in daylight illuminants. In: Proceedings of the 29th CIE SESSION (Washington, 2019). Vienna: International Commission on Illumination; 2019. p. 195-204; doi: https://doi.org/10.25039/×46.2019. OP31.

30. Luo MR, Cui G, Rigg B. The development of the CIE 2000 colour-difference formula: CIEDE2000. Color Res Appl. 2001;26(5):340-50. https://doi.org/ 10.1002/col.1049

31. Del Hoyo-Meléndez JM, Mecklenburg MF. An investigation of the reciprocity principle of light exposures using microfading spectrometry. Spectrosc Lett. 2011:44(1):52-62. https://doi.org/10.1080/0038701090 3508572

32. Melgosa M, Hita E, Romero J, Jiménez del Barco L. Some classical color differences calculated with new formulas. J Optical Soc Am 1992;9(8):1247-54. https://doi.org/10.1364/JOSAA.9.001247.

33. Huang M, Liu H, Cui G, Luo MR, Melgosa M. Evaluation of threshold color differences using printed samples. J Opt Soc Am. 2012;29(6):883-91. https://doi.org/10.1364/JOSAA.29.000883.

34. Cabello-Briones C, Mayorga-Pinilla S, Vázquez-Moliní D. Particulate dry deposition on sheltered archaeological remains: Considerations based on Complutum, a Roman site in Spain. J Cult Herit. 2020;46:218-25. https:// doi.org/10.1016/j.culher.2020.07.005.

\section{Publisher's Note}

Springer Nature remains neutral with regard to jurisdictional claims in published maps and institutional affiliations. 